\title{
ANALYSIS OF EXTERNAL SOURCES OF HAZARDS IN CIVIL AIR OPERATIONS
}

\section{Assoc. Prof., PhD Ing. Katarzyna Chruzik \\ PhD candidate, MA Karolina Wiśniewska PhD candidate, MA Radosław Fellner}

Department of Aviation Technologies, Transport Faculty, Silesian University of Technology, Krasińskiego 13, Katowice, Poland

e-mail:katarzyna.chruzik@polsl.pl

This article attempts to execute the first stage of risk management for civil air operations. Therefore it is necessary to identify and classify external sources of hazards. Risk management is one of the most important tools of modern systemic approach to process modeling. Generally, it may be described as a system of interrelated actions and decisions aimed at integration and coordination of processes in the organization, in cooperation with the external parties. The aim of management is therefore to improve the proficiency, effectiveness and efficiency of the operation and - in the case of risk management arising from the transport processes - to improve flight safety. The publication describes a proposal of risk management method in air transport including analysis of external threats to civil air operations.

KEYWORDS safety, risk analysis, sources of hazards, air transport, airport

\section{INTRODUCTION}

Air transport is a highly complex system linking advanced technical measures, the human, organizational and environmental factors. All those elements are closely connected, as well as have an impact on each other and are mutually supportive. In the era of proactive approach to safety management, correctly kept process of risk management became the most important element. Proactive approach to risk management is used to prevent occurrences in air transport. It consists of data gathering in order to identify possible negative future outcomes or events, analyzing system processes and the environment to identify potential future hazards and initiating mitigat- 
ing actions. Introduction of proactive safety management strategy offers an opportunity to reduce the risk of an accident to an acceptable level by taking the necessary corrective and preventive measures to eliminate recurrence of similar incidents. The basis for the proactive safety management is systematic preventive work in the area of: hazard identification, risk analysis, taking actions adequate to the performance and results of the analyses. It is therefore important to distinguish, identify, classify all existing hazard sources and accident-prevention factors. Next, it is necessary to determine and quantify their relations and interdependencies in terms of sources which initiate hazard inside and outside organization.

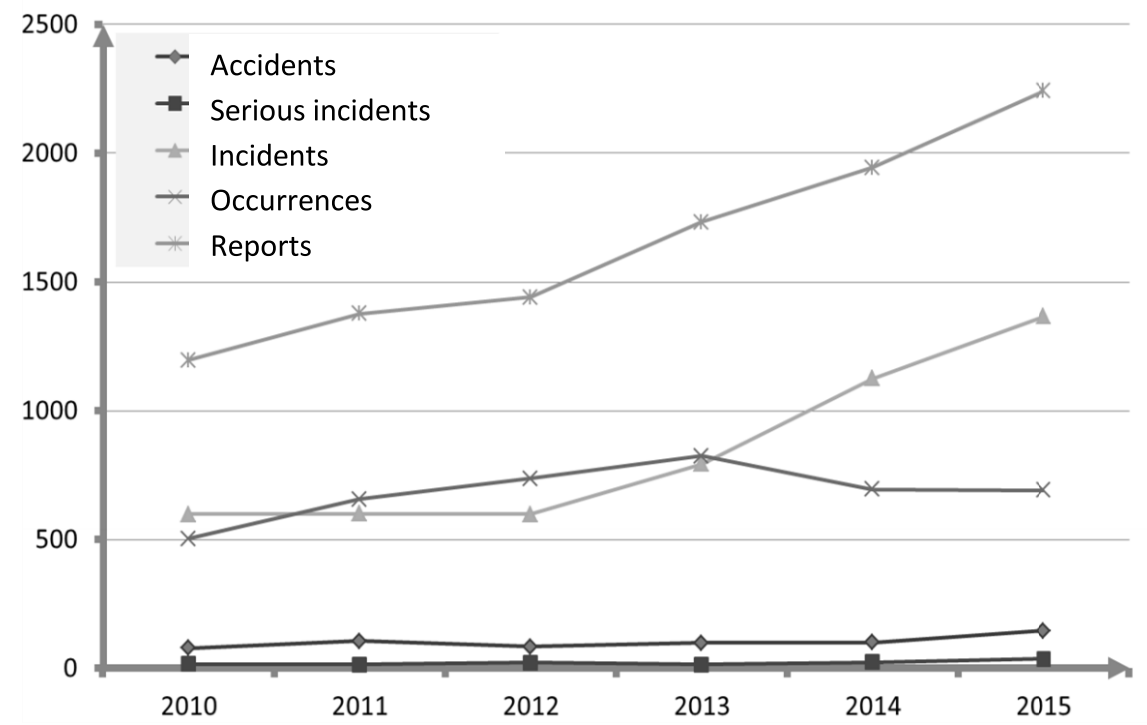

Figure 1. Applications of occurrences in the years 2005-2015 in the period from January 1 to October 26 Source: Lasek, 2015.

According to the European air law, hazard is defined as situation or an object with the potential to cause death or injury to a person, damage to equipment or a structure, loss of material, or a reduction of ability to perform a prescribed function, whereas aviation occurrence is a safety-related event which endangers or which, if not corrected or addressed, could endanger an aircraft, its occupants or any other person and includes in particular an accident or a serious incident (and includes accident, incident and serious incident) (Regulation EU No 376, 2014). From technical sciences perspective, aviation occurrence is a set of subsequent adverse sources of danger, whose appearance is random. Random events are subject to quantitative assessment based on previously available a priori information. Analyzing the number of reported aviation occurrences (fig. 1) it reveals a growing trend linked to the implemented safety culture in the following areas:

- Reporting Culture - free movement of information about occurrences and reporting any kind of mistake, which may increase safety, without fear of retribution or being punished,

- Informed Culture - chiefs, management supports efforts to understand risks and ability to identify hazards, 
- Just Culture - means a culture in which front line operators or others are not punished for actions, omissions or decisions taken by them that are commensurate with their experience and training, but where gross negligence, willful violations and destructive acts are not tolerated (Regulation EU No 376, 2014),

- Learning Culture,

- Flexible Culture.

This enables identification of new sources of threats, which may be used in risk management.

\section{RISK MANAGEMENT}

In practice, requirements in risk management in transportation must be divided into two basic approaches: operational (process and training) and strategic. Operational management means activity by objectives - description what is expected from each individual, organizational unit and each employee, as well as assessing what has been achieved and the formulation and implementation of plans for improvement. Strategic management is forecasting thinking about the phenomena and processes that will occur in the future and will create for organization/ state new operating conditions. It requires constant monitoring of the changes in the environment and their trends, assess the impact of these changes on the organization/area and their importance, capturing the most significant changes and identify key problems to be resolved (Krystek, 2009).

The presented method of risk management is based on two popular current methods of managing risk that recognize them as a systematic process that allows - step by step - to identify, plan and manage the risk of hazards during the planning and implementation of the project/process (Annex 19, 2013; Doc 9859, 2009; Guide..., 2013; PRINCE 2 ${ }^{\circledR}, 2009$; Pritchard, 2001):

- risk in Doc 9859 and Annex 19 (ICAO),

- risk in PMBoK Guide (Project Management Body of Knowledge),

- risk in PRINCE2 (PRojects IN Controlled Environments).

According to Annex 19 (2013) and Doc 9859 (2009), risk is a predicted probability and severity of the consequences or outcomes of a hazard. More specifically, safety risk is the projected likelihood and severity of the consequence or outcome from an existing hazard or situation (Regulation EU No 376, 2014). While the outcome may be an accident, an intermediate unsafe event/consequence may be identified as the most credible outcome. Provision for identification of such layered consequences is usually associated with more sophisticated risk mitigation software. What is more, safety risk management includes two crucial elements:

1. Hazard identification - which shall be based on a combination of reactive, proactive and predictive methods of safety data collection.

2. Safety risk assessment and mitigation - means maintenance and development a process that ensures analysis, assessment and control of the safety risks associated with identified hazards.

For comparison, in the model based on popular method (Guide to the Project Management Body of Knowledge, 2013):

- planning in risk management,

- hazard identification,

- quantitative hazard analysis,

- qualitative hazard analysis,

- planning of response to hazards,

- monitoring and controlling hazards. 
Due to the range of impact and special legal requirements, methods of risk assessment are described for operational risk:

- procedural - short time horizons relevant to the organization in terms of the main process,

- work-related - combination of the probability of adverse risks associated with work and resulting in losses as well as their implications for health or life of employees - in the form of occupational diseases and accidents at work (Kadziński, 2014).

\section{METHODS OF RISK MANAGEMENT IN AIR TRANSPORT}

Risk management refers to all the processes that, directly or indirectly, affect the main process of transport organization (transportation, infrastructure management, maintenance, production). In transportation industry there are used estimation of the risk and valuation of risks. Risk management method described in the article (fig. 2) is based on the created in companies and dynamically modified registers of threats, which at certain intervals are reviewed, expanded or modified with estimation and valuation of the risk threats. These activities allow direct management and precise setting of resources in the areas evaluated as unacceptable, while at the same time monitoring and communicating about hazards.

Risk management in transportation may be analyzed in many ways, depending on the:

- sources of analyzed risks (technical, organizational),

- objectivity/subjectivity of evaluation,

- risk assessment strategies (individual, social),

- evaluation method (qualitative, quantitative),

- the nature of losses,

- time horizon (operational risk, tactical, strategic risk),

- criterion admissibility of action (acceptable, tolerable, unacceptable risk).

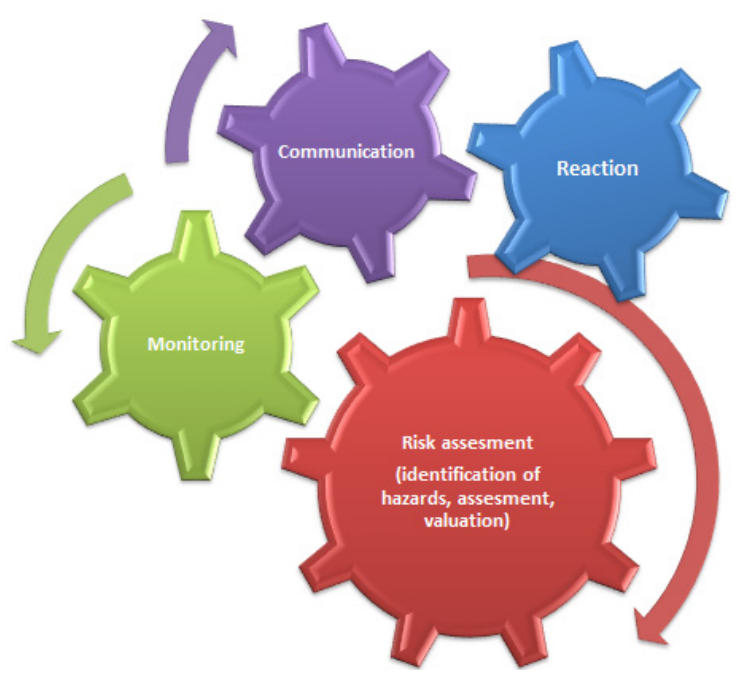

Figure 2. Risk management model in transport

Source: Chruzik, Fellner, 2016. 
Basing on the analysis of publication about risk assessment in transport, especially in air transport, safety is a state in which risks associated with aviation activities, related to, or in direct support of the operation, are reduced and controlled to an acceptable level (Kadziński, 2014). Sources of hazards are objects (e.g. physical, chemical, biological, psycho-physical, organizational, personal), whose presence in the specified area of the analysis, state, characteristics may be the cause (source) of the formulation of hazard. It is a similar definition to that of a cause which means actions, omissions, events, conditions, or a combination thereof, which led to the accident or incident (Regulation EU No 996/2010).

The combination of sources of threats and hazards may create real hazards that may (but do not have to) turn into an occurrence (fig. 3). The basis for risk management in transport is awareness of sources of hazards (based on historical data or experience), and thus awareness of specific hazards. This action enables to estimate identified hazards and - in case of exceeding the risk of hazards (area acceptable, tolerable, unacceptable) - to introduce corrective and preventive actions in processes, constant monitoring, as well as inform people directly involved in the process (employees) and its customers (passengers, bystanders) about the hazards (fig. 2).

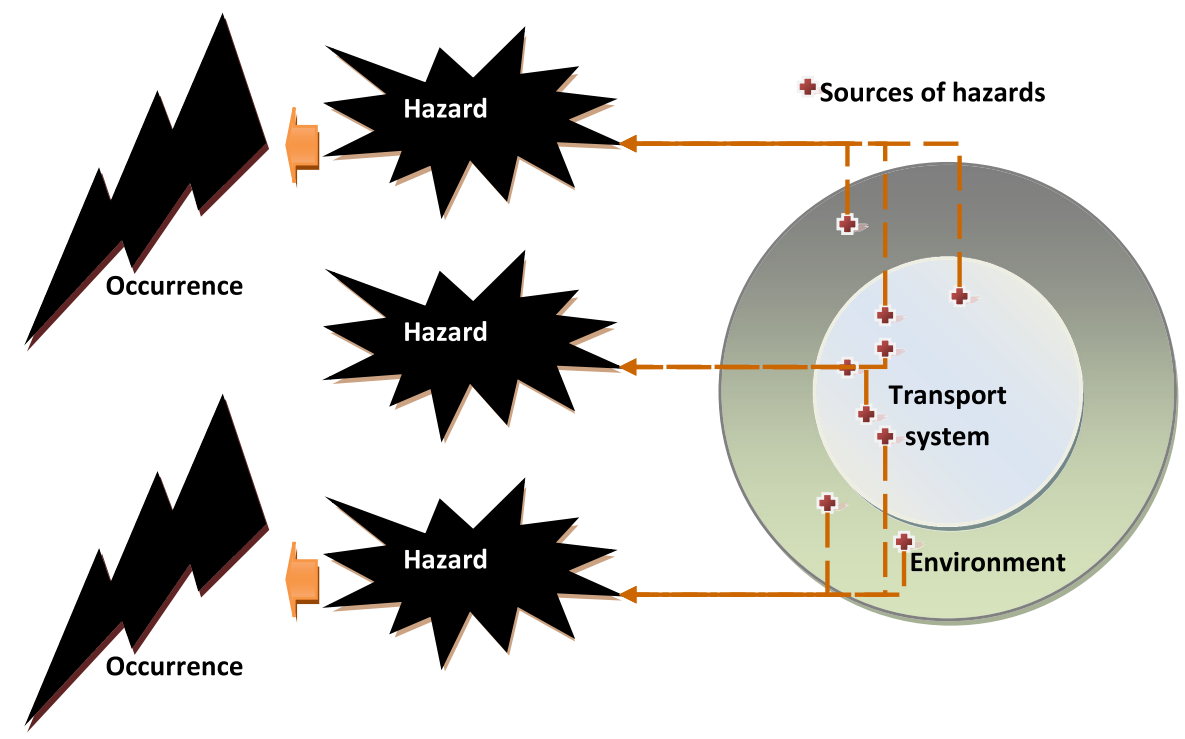

Figure 3. Scheme of initiation events

Source: Chruzik, Fellner, 2016.

Milestones in risk assessment, which determines the appropriate course of risk management and the associated safety measures are:

1. Risk Analysis - the process of systematic use of all available information to identify hazards including identification and classification of hazards with initial identification of acceptability of hazard risk. As a result of these actions there is made a hazard record for a system under area analysis. 
2. Risk assessment - defining scenarios and existing safety measures for identified hazards, and then estimation of magnitude of the effects that may occur in the case of occurrences as a result of identified hazards.

3. Valuation risk - the comparison of risk assessment results with determined criteria in order to answer if an acceptable level of risk is achieved.

Risk assessment usually consists of the following stages:

1. Analysis of all processes related to organization

The objective of this stage is to review all the processes performed by organization. Possible areas of hazards should be analyzed in relation to processes/activities (defining an area of possible hazards) e.g.: process of realization transport, personnel management, maintenance of vehicles/aircraft and technical resources, communication process, process of document management, processes related to activities of suppliers and coordination activities. The details of the review are basis for risk management.

2. Hazards identification

The objective of this stage is to create and develop a list of possible risks in organization, taking into account shared hazards arising from the activities of third parties (including social risk) and initial designation of consequences. All identified types of hazards are recorded in the "Hazard record".

3. Risk assessment

The purpose of this stage is to give value for identified hazards starting from such factors as:

$\mathrm{P}$ - probability of occurrence of a hazard (potential threats). The only way to minimize or even reduce probability is to incorporate defenses or preventive controls to eliminate the causes of errors.

$\mathrm{S}$ - possible consequences or outcomes of a hazard/event.

To sum up, risk is a predicted probability and severity of the consequences or outcomes of a hazard, which may be calculated with equation:

$$
\mathrm{R}=\mathrm{P} \cdot \mathrm{S}
$$

where:

$\mathrm{P}$ - probability of a hazard

$\mathrm{S}$ - severity of the consequences

Depending on the method, the number of factors determining the value of risks may vary, e.g. FMEA method provides identification detection of hazards scale.

4. Verification of the effectiveness of the control/preventive measures

Implementation of recommended corrective and preventive actions should be continuously monitored, and their effects should be a subject to verification by the method used for risk assessment. After timing of the implementation of control/prevention measures, there should be an evaluation of the process and calculation of a new risk index R. If the class of risk for a particular hazard exceeds the accepted threshold, it is necessary to define additional risk control measures, in line with its strategy. Moreover, a person responsible for implementing the actions should be assigned. After completing the planned scenario the assessment body checks again the level of hazard risk. If satisfactory level is achieved, the procedure is completed. Otherwise, additional measures should be taken. The whole process is stored in a dedicated form or a document. 
A very important element of risk management is identification of own risk (source of hazards and activation of threats is on the same transport organization), but also in the area of shared risk (sources of hazards are beyond transport system) and external risk (sources of hazards are outside the transport system). The overall risk in transport organization should consider all three risk areas (fig. 4):

$$
\mathrm{R}=\mathrm{R}_{\text {own }}+\mathrm{R}_{\text {shared }}+\mathrm{R}_{\text {external }}
$$

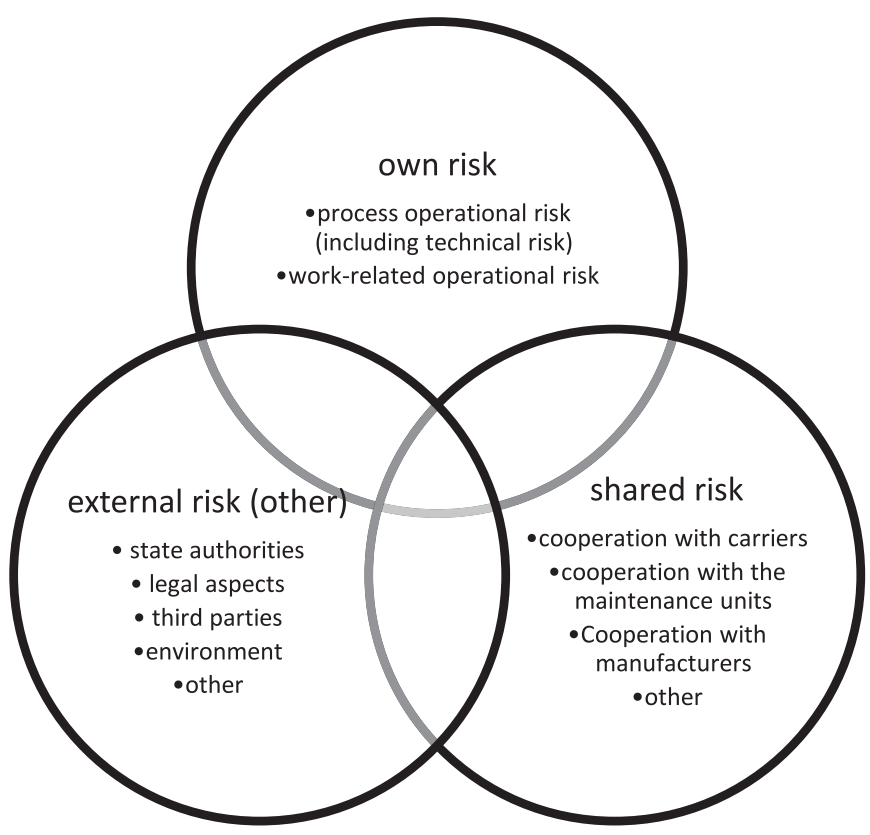

Figure 4. The area to identify sources of danger

Source: own study.

\section{EXTERNAL SOURCES OF HAZARDS IN CIVIL AIR OPERATIONS}

In this article the authors present the identification of hazards for Katowice Airport (EPKT). The choice of this airport specifically was not coincidental. EPKT is one of the largest regional airports in Poland. Any other risk identification (taking into account a new sources of hazard like drones or combined sources of hazards) has not been performed. So, it is justified to make such risk identification.

For the purpose of classifying sources of hazards there were used data from decree no. 14 of President of Polish Civil Aviation Authority (Zarządzenie..., 2006). On that basis, there was made a register of external sources of hazards in civil air operations (table 1). 
Table 1. Sources of external hazards for EPKT airport

\begin{tabular}{|c|c|}
\hline Human factor $(\mathrm{H})$ & Examples of hazards \\
\hline 1 & 2 \\
\hline Intentional (H.I) & $\begin{array}{l}\text { 1. Mental illness } \\
\text { 2. Political Terrorism } \\
\text { 3. Financial Terrorism } \\
\text { 4. Fundamentalism } \\
\text { 5. Alcohol } \\
\text { 6. Drugs/legal highs, designer drug } \\
\text { 7. Prohibited articles } \\
\text { 7.1. Explosives } \\
\text { 7.2. Long weapons } \\
\text { 7.3. Long firearms } \\
\text { 7.4. Sharps } \\
\text { 7.5. Bacteria/Viruses } \\
\text { 7.6. Radioactive materials } \\
\text { 8. Pneumatic weapon } \\
\text { 8.1. Shoulder-fired anti-aircraft missiles, rocket launchers } \\
\text { 8.2. Grenades } \\
\text { 8.3. Small arms and light weapons } \\
\text { 9. False Alerts } \\
\text { 10. Lasers } \\
\text { 11. Drones, Unmanned Aerial Vehicle, Remotely Piloted Aircrafts } \\
\text { 12. Theft of technical measures } \\
\text { 13. Hackers } \\
\text { 14. Fires near the airport } \\
\text { 15. Vandalism }\end{array}$ \\
\hline $\begin{array}{l}\text { Non-intentional } \\
\text { (H.N) }\end{array}$ & $\begin{array}{l}\text { 1. Nervousness during security checks } \\
\text { 2. Willingness to help fellow passenger } \\
\text { 3. Panic } \\
\text { 4. Bacteria and viruses } \\
\text { 5. Irradiation } \\
\text { 6. Lack of awareness of the consequences (O.1) } \\
\text { 7. Unauthorized flying objects } \\
\text { 7.1. Drones } \\
\text { 7.2. Models of flying vehicles } \\
\text { 7.3. Paragliders, paramotors, powered parachute } \\
\text { 7.4. Balloons/lanterns } \\
\text { 8. Fireworks } \\
\text { 9. Fires near the airport }\end{array}$ \\
\hline $\begin{array}{l}\text { Technical factor } \\
\text { (T) }\end{array}$ & $\begin{array}{l}\text { 1. Disruption due to external technical measures and protection } \\
\text { 2. Unauthorized access to the ground-based facilities } \\
\text { 3. Unauthorized access to the aircraft } \\
\text { 4. Design errors of technical measurements } \\
\text { 5. The accumulation of flammable substances }\end{array}$ \\
\hline $\begin{array}{l}\text { Environmental } \\
\text { factor (E) }\end{array}$ & $\begin{array}{l}\text { 1. Weather anomalies } \\
\text { 1.1. Fierce gusts of wind } \\
\text { 1.2. Whirlwinds } \\
\text { 1.3. Fog } \\
\text { 1.4. Heavy rain } \\
\text { 1.5. Heavy snowfall/Blizzards } \\
\text { 1.6. Turbulences } \\
\text { 2. Fires near the airport } \\
\text { 3. The eruption of volcanoes } \\
\text { 4. Mammals }\end{array}$ \\
\hline
\end{tabular}




\begin{tabular}{|l|l|}
\hline 1 & \\
\hline & 5. \\
& 6. \\
& 7. Flood threats \\
& 8. High grass at the airport \\
\hline Organizational & 1. Lack of awareness „culture of safety” (H.N.6) \\
factor (O) & 2. Lack of knowledge of the airport requirements \\
& 3. High concentration of people in a small space \\
& 4. "Important” events \\
\hline
\end{tabular}

Source: own study based on Zarządzenie Nr 14..., 2006.

Table 2. Identified groups of hazards

\begin{tabular}{|c|c|c|}
\hline No. & Group of hazards & Sources of hazard \\
\hline 1. & Runway Incursions & H.I.1-7, H.I.11, H.N.2, H.N.6-7, T.1-2, E.4, E.6-8, O.1, o.4 \\
\hline 2. & Runway Excursions & H.I.1-8, H.I.10-15, H.N.2, H.N.7, T.1-4, E.1, E.4, E.7-8, O.4 \\
\hline 3. & Mid-air Collisions & H.I.11, H.I.13, H.N.7, T.1-4, E.5 \\
\hline 4. & Controlled Flight into Terrain & H.I.1-8, H.I.10-13, H.N.2-8, T.1-5, E.1, E.5, E.7, E.8, O.1, O.4 \\
\hline 5. & Loss of Control In Flight & H.I.1-8, H.I.10-13, H.N.2-8, T.1-5, E.1, E.3, E.5, E.7-8, O.1, O.4 \\
\hline 6. & Intrusion into Controlled Airspace & H.I.1-6, H.I.11, H.I.13, H.N.7, H.N.9, T.1, T.4, E.2 \\
\hline 7. & Fire, smoke and fumes & $\begin{array}{l}\text { H.I.1-8, H.I.12, H.I.14-15, H.N.3, H.N.5, H.N.8-9, T.1-5, E.1-5, O.1, } \\
\text { O.3-4 }\end{array}$ \\
\hline 8. & Intrusion into restricted area of airport & H.I.1, H.I.5-6, H.I.11-15, T.1-5, E.1.3, O.1-2 \\
\hline 9. & $\begin{array}{l}\text { Intrusion into restricted area of airport } \\
\text { with prohibited items }\end{array}$ & H.I.1-9, H.I.11-5, T.1-5, E.1.3, O.1-2, O.4 \\
\hline 10. & Bomb threat in buildings and facilities & H.I.1-7, H.I.9, H.I.11, H.I.13, H.N.2-3, H.N.6, T.1-3, T.5, O.3-4 \\
\hline 11. & Bomb threat on board of the aircraft & H.I.1-7, H.I.9, H.I.13, H.N.2-3, H.N.6-7.1, T.1-3, T.5, O.3-4 \\
\hline 12. & Hostages at airport area & H.1-7, H.I.11, H.I.13, H.N.2-3, T.1-3, O.3-4 \\
\hline 13. & $\begin{array}{l}\text { Unlawful seizure of civil aircraft with } \\
\text { passengers }\end{array}$ & H.1-7, H.I.11, H.I.13, H.N.2-3, T.1-3, T.5, O.3-4 \\
\hline 14. & $\begin{array}{l}\text { Unlawful seizure of civil aircraft } \\
\text { without passengers }\end{array}$ & H.1-7, H.I.11, H.I.13, H.N.2, T.1-3, T.5, O.4 \\
\hline 15. & $\begin{array}{l}\text { Landing unlawful seizured civil aircraft } \\
\text { at airport }\end{array}$ & H.I.1-.7, H.I.13, H.N.2, H.T.1-3, O.4 \\
\hline 16. & Acts of sabotage or diversion & H.I.1-15, H.N.2-3, T.1-3, T.5, O4 \\
\hline 17. & Public order disturbances, vadalism & H.I.1, H.I.5-6, H.I.9-15, H.N.1-9, T.1-3, T.5, E.1-3, O.1-4 \\
\hline 18. & $\begin{array}{l}\text { Aircraft crashesnot related to human } \\
\text { activity (weather anomalies) }\end{array}$ & E.1-8 \\
\hline 19 & $\begin{array}{l}\text { Damage of technical facilities with } \\
\text { consequences }\end{array}$ & H.I.1, H.I.5-6, H.I.10-15, H.N.6-7, T.1-5, E.1-8, \\
\hline
\end{tabular}

Source: own study based on EASp, 2014 and www.ulc.gov.pl.

The groups of hazard described in table 2 highlight many possible combinations of hazards sources. All the mentioned groups are conditioned by factors from external threats. On such threats the airport has a limited influence. Risk areas have been divided into those associated with human activity (the human, technical and organizational factors) and those for which a person has a limited influence (the environmental factor). The groups of hazards involving humans are divided into two areas: intentional and unintentional. Intentional sources of hazards are the most 
common activities aimed at committing an act of unlawful interference by acts of terrorism, acts of vandalism, or dictated by religious beliefs. A frequent source of danger in this area is also a mental illness. Unintentional sources of threats are determined by ignorance of the law or consequences and lack of awareness of the consequences.

For example, intrusion into a restricted area of the airport with prohibited articles may be caused by variety of sources, both intentional and unintentional. It may be caused by the organization or it may be the result of technical factors. Due to the highly developed system of civil aviation security, entering the prohibited item into a security restricted area may be the result of the compilation of several sources of danger. In other words, at least one element of the system of protection would need to fail, while at the same time, someone would try consciously or unconsciously to bring a prohibited item into the airside. Examples of components from these groups of hazards may be:

1. HN2 - willingness to help a fellow passenger

This hazard is understood also as a consequence of ignorance. For example, a passenger flying on the same flight asks another stranger passenger (staying in queue to security check) to take some of his items. The stranger passenger agrees. At the security check, it turns out that the item is not allowed to be taken on board and putting it in a fellow passenger's hand was merely an attempt to smuggle it aboard without any consequences in the event of its detection.

2. $\mathrm{O} 2$ - lack of knowledge of the airport's requirements

In order to ensure international safety standards, the airport introduces various systemic solutions. Ignorance of the requirements increases the risk of danger.

3. HI2 - political terrorism

The use of violence or threatened use of violence (terror), often targeting civilians, in order to change a political system, introduction of legal solutions or separation of part of state's territory.

4. HI3 - financial terrorism

The use of violence or threatened use of violence (terror), often targeting civilians, in order to achieve of a tangible asset, goods or financial gain.

5. HI4 - fundamentalism

Attitude with religious connotation that indicates unwavering attachment to a set of irreducible beliefs. In recent years Islamic fundamentalism has become the most dangerous (especially such formations as: Al-Qaeda, Hezbollah, Hamas, ISIS/Deash).

6. HI11 - drones, Unmanned Aerial Vehicle, Remotely Piloted Aircraft

Unmanned Aerial Vehicles, also known as Remotely Piloted Aircraft, called "drones", have become a serious threat to air transport. They might be used as a tool for fighting and attack, including:

- carrier an explosives,

- carrier chemical or biological weapons,

- using UAV as a missile itself, e.g. in a restricted area,

- jamming signals,

- using UAV as a platform to hack airport's information systems and computers.

7. O4 - "important" events

Important events means huge organizational actions which take place at a certain time and provide a good opportunity to commit an act of unlawful interference due to the large number of people, fans at airports, especially passengers traveling by air. Examples of such important events are: World Youth Days, NATO, UN and EU summits, sports tournaments. 
The above mentioned sources of hazards combined with each other create conditions to get prohibited items or an unauthorized person into a restricted area at an airport, which is illustrated by the following example:

$\mathrm{HN} 2+\mathrm{HN} 6+\mathrm{HI} 7+\mathrm{HI} 1=$ risk of unlawful intrusion to restricted area at an airport with prohibited items (table 2)

where:

HN2 - Willingness to help a fellow passenger

HN6 - Lack of awareness of the consequences

HI7 - Prohibited articles

HI1 - Mental illness

Here is an example of a real possible situation that might arise from the combination of these four sources of hazard:

A person with a mental illness (called "passenger X"), having prohibited articles planned to bring to the restricted area in order to commit an act of unlawful interference on board of an aeroplane. Passenger X has a number of parts of weapons, which if put in one luggage, certainly would generate suspicion of an operator at the security check desk and would block off the entrance to the restricted area. With this in mind, passenger X decides to use another person traveling on the same flight (called "passenger Y") who is not aware of the intentions of passenger X. Items placed separately are not suspicious by themselves, only their combination makes this object possible to be used to commit an act of unlawful interference. Passenger $\mathrm{X}$ asks passenger $\mathrm{Y}$ to take a few things due to the large amount of luggage. Passenger $\mathrm{X}$ explains their request by saying they have already exceeded the weight limit of luggage which is allowed without incurring additional charges. Passenger $Y$ accepts these arguments and agrees to help passenger $\mathrm{X}$, not knowing that among those things there are also items that might be used to prepare a prohibited item (for example a weapon). After the security check passenger $\mathrm{X}$ receives from the passenger $Y$ their things and at the same time becomes the owner of all the elements of a prohibited item, in the restricted area of the airport.

Estimating the value of this group of hazards for sources declared in this example (for 10-point scale the likelihood and impact), it may be set up that the product of probability equals " 3 " with the same value of effects, which gives the value of the hazard on the level "9". The maximum value of these indicators $(10 \times 10)$ is 100 categorizing this hazard in the acceptable area. However, this situation may be analyzed for other sources of hazards (table 2):

$$
\mathrm{R}=\text { H.I. } 4 \text { + H.I.7.1 + H.N. } 2 \text { + H.N. } 6 \text { + O. } 3+\text { O. } 4
$$

The value of hazard to such scenario may change for the partial factors (much less likely than in the previous example at a much higher value of effects), although probably their product will be comparable. Risk estimation depending on the used method may be extended by additional factors like: possibility of detection, number of people exposed, frequency of exposure, etc.

The analysis shows many of possible combinations of hazards in the area of external sources for the aviation system.

\section{CONCLUSION}

The growing number of aircraft and operations which they perform created needs to develop more precise rules relating to the data collection, reporting, analysis and follow-up of occurrences in civil aviation. It is necessary to make a comprehensive analysis of the risks associated with 
the air operation of aircraft - particularly inside and outside of airports. The objective of risk management is to eliminate, or - if this is not possible - reduce the size of the damage that might be caused by transport events and aviation occurrences. It is important to take into account all the possible actions which should be implemented before the event occurs and should be based on hazard analysis (proactive approach). This article shows the first part of consideration in the field of external hazard sources and will be continued in other areas of transportation. Conducted experiments and tests also suggest that in such risk analysis it is worth to take into account unlikely hazards (which are a compilation of the most unlikely sources of hazards). The most severe are the effects of improbable events (it refers to such crashes as the railway disaster in Szczekociny or the plane crash in Smoleńsk). The basis for a proper risk management process is correct identification of the sources of hazards in all areas of air transport.

\section{REFERENCES}

Annex 19. (2013). Safety Management, ICAO, 1st edition, Montreal.

Annex 13. (2010). Aircraft Accident and Incident Investigation, ICAO, 10th edition, Montreal.

Chruzik, K. (2016).Inżynieria bezpieczeństwa w transporcie, Wydawnictwo Politechniki Śląskiej, Gliwice. Doc 9859. (2009). Safety Management Manual (SMM). ICAO, p. xii.

Guide to the Project Management Body of Knowledge. (2013). 5th edition. PMI.

Lasek, M. (2015). Omówienie stanu bezpieczeństwa w 2015 r. Konferencja Bezpieczeństwa Lotów Lotnictwa Cywilnego - rok 2015, PKBWL.

PRINCE2 $2^{\circ}$. Crown.

Pritchard, C. (2001). Zarzadzanie ryzykiem w projektach. WIG-Press, Warszawa.

Regulation (EU) No 996/2010 of the European Parliament and of the Council of 20 October 2010 on the investigation and prevention of accidents and incidents in civil aviation and repealing Directive 94/56/ EC, Official Journal of the European Union L 295, 12.11.2010, p. 35-50.

Regulation (EU) No 376/2014 of the European Parliament and of the Council of 3 April 2014 on the reporting, analysis and follow-up of occurrences in civil aviation, amending Regulation (EU) No 996/2010 of the European Parliament and of the Council and repealing Directive 2003/42/EC of the European Parliament and of the Council and Commission Regulations (EC) No 1321/2007 and (EC) No 1330/2007, Official Journal of the European Union L 122, 24.4.2014, p. 18-43.

Kadziński, A. (2014). Rozdział 3. [In:] L. Lewicki, J. Wrzesińska. (eds). Podręcznik: Istotne aspekty BHP, Poznań.

Krystek, R. (ed.). (2009). Zintegrowany System Bezpieczeństwa Transportu, Tom II: Uwarunkowania rozwoju integracji systemów bezpieczeństwa transportu, Warszawa.

Załęski, K., Compa, T. (2013). Wybrane aspekty bezpieczeństwa w portach lotniczych. Logistyka, 6/2013, p. 490-499.

Zarządzenie Nr 14 Prezesa Urzędu Lotnictwa Cywilnego z dnia 14 grudnia 2006 r. w sprawie wprowadzenia klasyfikacji grup przyczynowych zdarzeń lotniczych, Dz. U. ULC z dn. 29 grudnia 2006 r., poz. 43.

Zieliński, M. (2010). Bezpieczeństwo w porcie lotniczym. Zeszyty Naukowe Akademii Marynarki Wojennej, 51/2010, p. 157-180.

European Aviation Safety Plan (EASp) 2014-2017, EASA, Brussels 2014.

www.ulc.gov.pl.

Chruzik, K., Fellner, A. (2016). Polish transport safety platform. Scientific Journal of Silesian University of Technology. Series Transport. 90, p. 25-36. ISSN: 0209-3324. DOI: 10.20858/sjsutst.2016.90.3. 


\section{Analiza zewnętrznych źródeł zagrożeń cywilnych operacji lotniczych}

STRESZCZENIE Celem artykułu jest wykonanie pierwszego etapu procesu zarządzania ryzykiem dla cywilnych operacji lotniczych, dlatego niezbędne jest zidentyfikowanie i sklasyfikowanie zewnętrznych źródeł zagrożeń. Zarządzanie ryzykiem jest jednym z najważniejszych narzędzi współczesnego systemowego podejścia do modelowania procesów. Najogólniej zobrazować je można jako system wzajemnie powiązanych działań i decyzji, mających na celu integrację i koordynację procesów w organizacji przy współpracy $\mathrm{z}$ otoczeniem zewnętrznym. Celem zarządzania jest więc poprawa sprawności, skuteczności i efektywności funkcjonowania, a w przypadku zarządzania ryzykiem wynikającym z procesów transportowych poprawa bezpieczeństwa lotów. W publikacji opisano propozycję metody zarządzania ryzykiem $\mathrm{w}$ transporcie lotniczym $\mathrm{z}$ analizą zewnętrznych źródeł zagrożeń cywilnych operacji lotniczych.

SŁOWA KLUCZOWE bezpieczeństwo, analiza ryzyka, źródła zagrożeń, transport lotniczy, port lotniczy

Translated by Radosław Fellner 